\title{
LABORATORY TESTING RESULTS OF KINETICS AND PROCESSING TECHNOLOGY OF THE POLYMETALLIC SULPHIDE CONCENTRATE BLAGOJEV KAMEN - SERBIA
}

\author{
Milorad Ćirković $^{1 *}$, Željko Kamberović $^{2}$, Mile Bugarin ${ }^{1}$ \\ ${ }^{I}$ Mining and Metallurgy Institute Bor, Zeleni bulevar 35,Bor, Serbia, \\ ${ }^{2}$ Faculty of Technology and Metallurgy, Belgrade, Serbia
}

Received 11.05.2016

Accepted 21.06.2016

\begin{abstract}
This work presents the laboratory testing results of kinetics the oxidation process and sample processing of the sulphide polymetallic concentrate Blagojev Kamen. The aim of investigation is recovery of these types of raw material, present in large quantities in the peripheral parts of already used primary mineral deposits of copper, because of their high economic potential due to the content of a large number of metals and especially precious metals. Characterization of this raw material is based on the chemical analyses, XRD results, DTA analysis, etc. For these investigations, the sulphide concentrate with the following content was used in \%: $\mathrm{Cu}-2.3 ; \mathrm{Fe}-19.8 ; \mathrm{S}-$ $27.19 ; \mathrm{Zn}-9.13 ; \mathrm{As}-0.167 ; \mathrm{Pb}-15.63 ; \mathrm{SiO}_{2}-17.93 ; \mathrm{CaO}-0.97 ; \mathrm{Al}_{2} \mathrm{O}_{3}-1.43 ; \mathrm{Ag}-$ $480 \mathrm{~g} / \mathrm{t} ; \mathrm{Au}-659 \mathrm{~g} / \mathrm{t}$. Kinetic investigations of oxidation processes were carried out under the isothermal conditions within the temperature range of 400 to $625^{\circ} \mathrm{C}$. The Sharp's model was used for determination the kinetics parameters, and determined values of activation energy are $67 \mathrm{~kJ} / \mathrm{mole}$ for the first period, and $47 \mathrm{~kJ} / \mathrm{mole}$ for the second period. Pyrometallurgical treatment of this type of polymetallic concentrate, in the laboratory conditions, was carried out using the oxidative roasting and, then the reduction smelting was done in the Taman's furnace. Gold from 90.5 to $97.95 \%$ and silver from 77.28 to $93.37 \%$ are moved into the raw lead (smelting product). Gold from 1.1 to $3.92 \%$ and silver from 4.35 to $8.42 \%$ are moved into the polymetallic copper matte. Gold from 0.58 to $1.6 \%$ and silver from 2.45 to $6.82 \%$ are moved into the slag.

Keywords: polymetalic concentrate, oxidation, kinetics, Sharp
\end{abstract}

\section{Introduction}

The aim of investigation is the recovery of these types of raw material, present in large quantities in the peripheral parts of already used primary mineral deposits of

* Corresponding author: Milorad Ćirković, milorad.cirkovic@irmbor.co.rs 
copper, because of their high economic potential due to the content of a large number of metals and especially precious metals: $\mathrm{Cu}, \mathrm{Fe}, \mathrm{S}, \mathrm{Pb}, \mathrm{Zn}, \mathrm{Au}, \mathrm{Ag}$. Goldbearing quartz Blagojev Kamen was subjected to the flotation process. Product of flotation concentrate with content of $659 \mathrm{~g} / \mathrm{t} \mathrm{Au}$ and $480 \mathrm{~g} / \mathrm{t} \mathrm{Ag}$. Remaining constituents in the concentrate are: As, Cd, Se, Mn, Sn, Ni, Bi, Ti, Mo, V, Co.

The knowledge of mechanism and kinetics of oxidation processes of metallic sulphides is the subject of great significance in practical applications [1-3]. Sulphides from the system $\mathrm{Fe}-\mathrm{Pb}-\mathrm{Zn}-\mathrm{S}$ under oxidation processes were investigated by many researches [4-6], due to importance of those sulphides in metallurgy. However, the documentation is still incomplete and some discrepancy may be noticed by comparing different references. The starting characterisation of the investigated sample was done based on the chemical analysis, XRD results, DTA analysis as well as the constructed Phase Stability Diagrams (PSD) for system. Kinetic investigations of oxidation process were carried out under isothermal conditions (temperature range $400-625^{\circ} \mathrm{C}$ ). The obtained degrees of desulphurization were used in process calculation according to Sharp's model [7] and kinetic parameters for oxidation process were determined, including activation energies and rate constants of characteristic reactions.

Today, in the world, for gold extraction from sulphide ores and concentrates, the pyrometallurgical methods are used more and more, and the technologies as cianization and amalgamation $[8,9]$ are left. The basic reason for this is in higher recovery of gold and dificulties in use and living and environment protection in work with cyanides.

In the process of pyrometallurgical extraction of precious metals there is always the basic phase - collector, where precious metals are collected. Selection of collector phase depends on content the starting raw material, further metallurgical treatment and other factors. In metallurgical treatment of suphide gold bearing concentrates as collector, the most usable are lead, copper or calcine. Lead is traditionally used as a collector for precious metals due to high dissolubility of precious metals in lead at low temperatures, rapid separation of lead by pyrometallurgical method (cupellation process) and low working temperature (up to $1000^{\circ} \mathrm{C}$ ). This is especially if goldbearing concentrate or secondary raw materials contain significant quantity of lead. The main shortage of lead as collector is the required rigorous control of environment pollution and unsatisfactory recovery of $\mathrm{I}, \mathrm{Ru}$ and $\mathrm{Os}$ in cupellation phase [10] .

In decision making on selection the collecting phase in certain situation, besides the above mentioned, the other facts have to be taken into consideration as well as : chemical content of concentrate, what in some cases could have a decisive influence, consumption of normative material, training of labour force and others.

This polymetallic goldbearing concentrate Blagojev Kamen, with content in (\%): $\mathrm{Cu}-2.3 ; \mathrm{Fe}-19.8 ; \mathrm{S}-27.19 ; \mathrm{Zn}-9.13 ; \mathrm{As}-0.167 ; \mathrm{Pb}-15.63 ; \mathrm{SiO}_{2}-17.93 ; \mathrm{CaO}-$ $0.97 ; \mathrm{Al}_{2} \mathrm{O}_{3}-11.43 ; \mathrm{Ag}-480 \mathrm{~g} / \mathrm{t} ; \mathrm{Au}-659 \mathrm{~g} / \mathrm{t}$ was undergone to the pyrometallurgical treatment (oxidation roasting - reduction smelting in a graphite tigel in the laboratory Taman's furnace).

\section{Experimental kinetic investigations}

Thermal behaviour and mass changes analysis of starting sample, during oxidation in non-isothermal conditions were performed using the results of DTA analysis. For the purpose of the thermal analysis Derivatograph-Q (MOM, Hungary) was used with the following conditions: sensitivity DTA - $1 \mathrm{mV}$ and DTG - $1 \mathrm{mV}, \mathrm{TG}-$ 
$100 \mathrm{mg}$, heating rate of $10^{\mathrm{O}} \mathrm{min}^{-1}$, sample mass $100 \mathrm{mg}$, and $\mathrm{T}_{\max }=1273 \mathrm{~K}$. A ceramic crucible was used. All experiments were carried out in the air atmosphere.

$\mathrm{X}$-Ray analysis was performed in order to characterize the starting investigated sample. The phase composition was determined on Siemens X-ray equipment with $\mathrm{Cu}$ anticathode and Ni filter at voltage $40 \mathrm{kV}$ and current $18 \mathrm{~mA}$.

Isothermal investigations were done using an electric resistance furnace with thermostatic control. A measured volume of air was introduced into the reaction area, while gaseous product of reaction (mostly $\mathrm{SO}_{2}$ ), passed from furnace tube to the absorption tubes, filled with aqueous solution of hydrogen peroxide, producing sulphuric acid. The produced sulphuric acid was reacted with measured standard solution of sodium hydroxide in the presence of indicator for the purpose of calculation the sulphur content and, hence degree of desulphurization during oxidation roasting was calculated with $\%$ of expected error as $\pm 0.1 \%$.

\section{Results}

\section{Starting Sample Characterization}

The Fe-Pb-Zn-S-O system was interest during the investigation of polymetallic concentrate oxidation in the air. Therefore, characteristic phase stability diagrams was constructed based on starting thermodynamic data for reactions occurring in the system of interest at temperatures of 573 and $1273 \mathrm{~K}$, as shown in Figures 1 and 2. Phase stability diagrams were constructed for the systems $\mathrm{Zn}-\mathrm{S}-\mathrm{O}$, Fe-S-O and Pb-S-O separately (respectively).

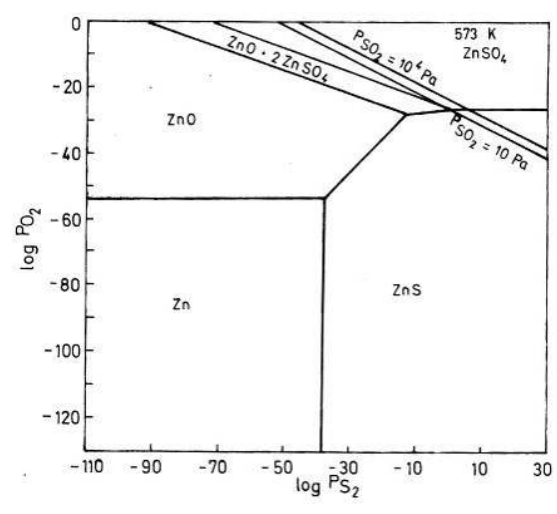

$a$

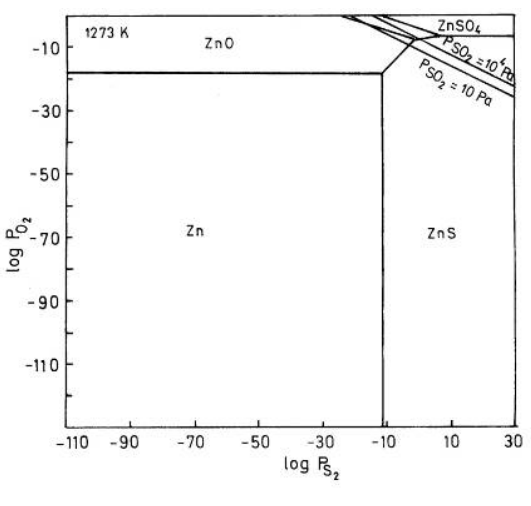

$b$

Fig.1. Phase stability diagrams for the system $\mathrm{Zn}-\mathrm{S}-\mathrm{O}$ : a) $300^{\circ} \mathrm{C}$ and b) $1000^{\circ} \mathrm{C}$ 

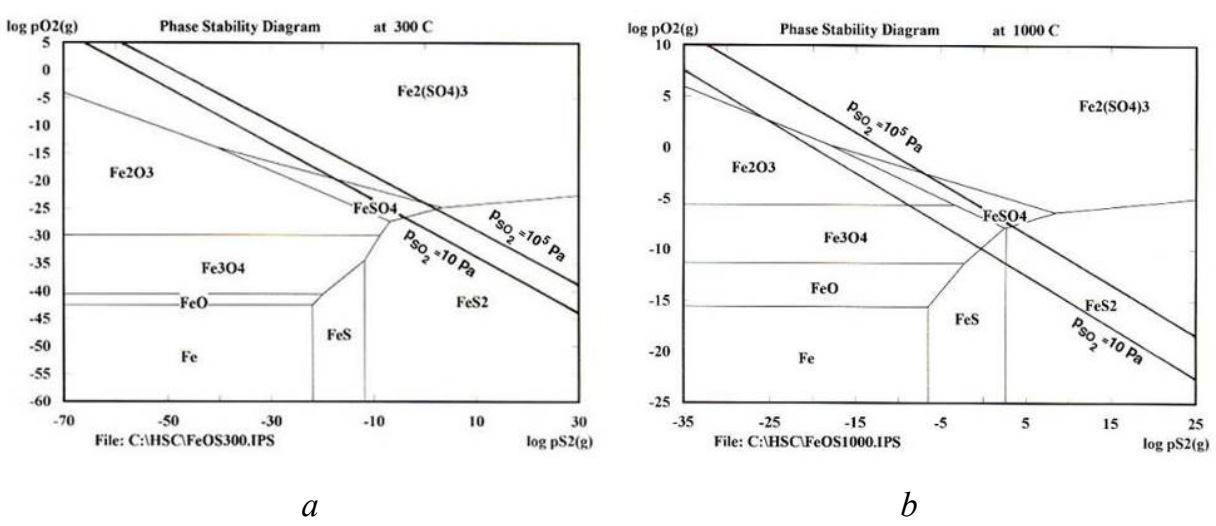

Fig. 2. Phase stability diagrams for the system $\mathrm{Fe}-\mathrm{S}-\mathrm{O}$ : a) $300^{\circ} \mathrm{C}$ and b) $1000^{\circ} \mathrm{C}$

The obtained results show equilibriums between phases, with indicated final product of the oxidation process for defined concentrations of $\mathrm{SO}_{2}$ and $\mathrm{O}_{2}$ in investigated systems.

The results of thermal analysis of investigated sample the polymetallic concentrate sample, obtained using DTA method, are presented in Figure 3, while the results of X-ray diffraction are presented in Figure 4.

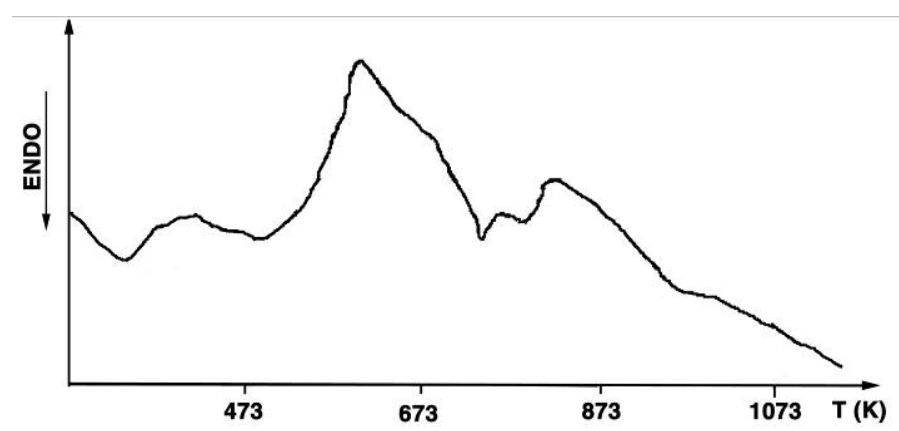

Fig. 3. DTA analysis of the Fe-Pb-Zn-S polymetalic concentrate sample oxidation (atmosphere - air, heating rate $-10^{\circ} \mathrm{min}^{-1}$ )

The first small endothermic peak at DTA curve, presented in Figure 3, occurs at temperature near $373 \mathrm{~K}$ that represents a removal of humidity from sample. The following exothermal peaks are for oxidation the sulphide samples until the corresponding sulphates are formed $\left(\mathrm{FeSO}_{4}, \mathrm{ZnSO}_{4}\right.$ and $\left.\mathrm{PbSO}_{4}\right)$. Final endothermic peak is for the sulphate dissociation to corresponding oxides and $\mathrm{SO}_{2}$. 


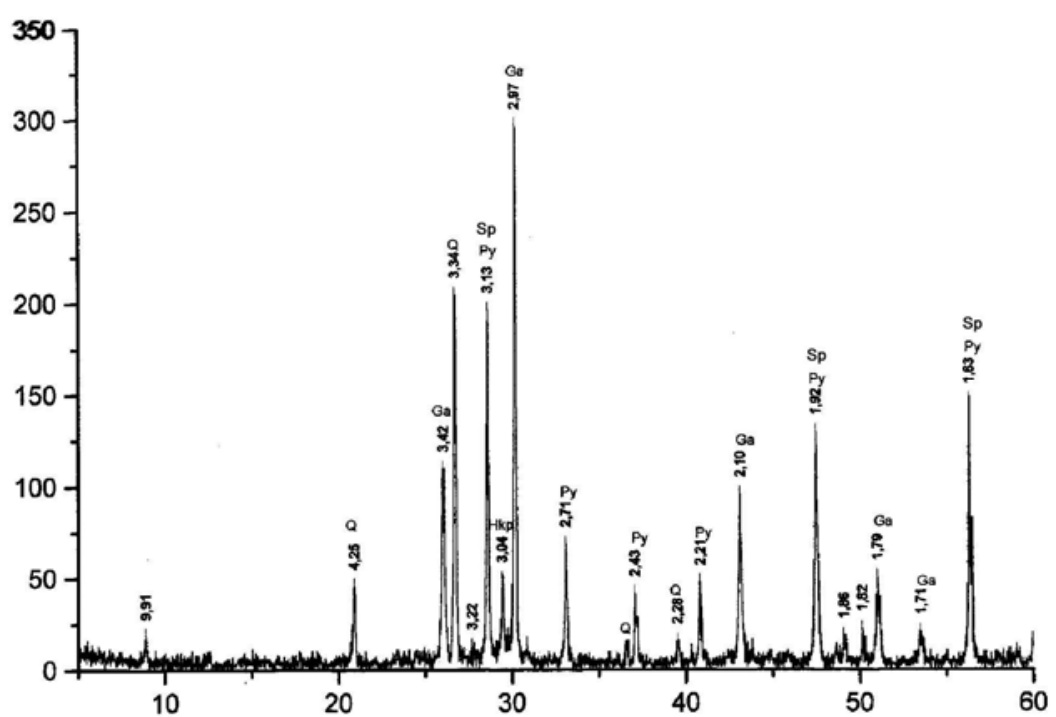

Fig. 4. X-ray ing diffractograms of the investigated startsample $(Q-q u a r t z$, Ga-galena, Py-pyrite, Hkp-chalcopyrite, Sp-sphalerite

According to the figure 4 dominating in the sample are well crystallised minerals from the sphalerite group mostly galena and pyrite (with sphalerite peaks partially covered with the pyrite), small amount of chalcopyrite is present as well. There is considerable amount of quarts present as well.

\section{Kinetics of Investigated Oxidation Process System}

Degree of desulphurisation was used for determination the kinetic parameters of oxidation using the Sharp's isothermal model [7], that was later. Degree of desulphurization presents the ratio of reacted sulphur during oxidation process, compared to starting concentration of sulphur in a sample.

In the course of experiments, samples were oxidized and amounts of emitted $\mathrm{SO}_{2}$ were successively registered. These results are presented in Figure 5. 


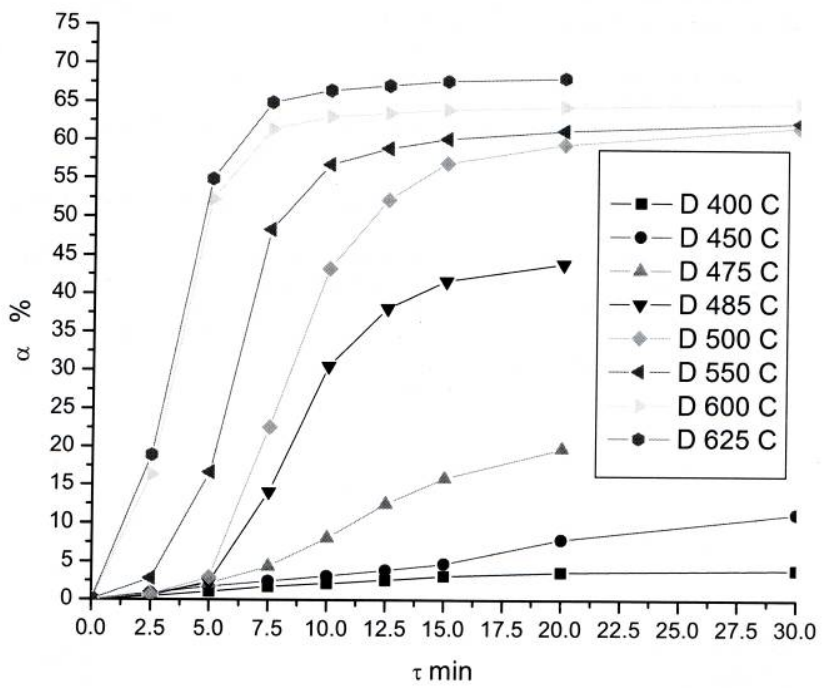

Fig. 5. Amount of sulfur reacted with oxygen during oxidative roasting of investigated sample ( $D$ - degree of desulfurization, $\tau$ - time)

Linearization of experimental results, presented in Figure 6, was tested using nine different kinetic equations, proposed by Sharp [7]. The criteria for accepting an equation as the best for linearization of the experimental data was the Sharp method of reduced half time of reaction. Using equation $\mathrm{A}_{2}: \quad[-\ln (1-\alpha)]^{1 / 2}=k \cdot t$ for desulphurization, where: $\alpha$ - degree of reaction, $\tau$-time, k-rate constant. Best linearization of experimental data was done, Figure 6. According to the Sharp's theory, equation $\mathrm{A}_{2}$ describes randomly nucleation of a new stage (Avrami I equation) [7]. This stage could be concerned as a dominant in controlling the reaction rate in the first period of time. It is obvious that change in reaction mechanism occurs after first 6-12 minutes of the process what is indicated with infraction of liberalized isotherms in Figure 6. From the slopes of liberalized isotherms, the rate constants were determined and characteristic Arrhenius diagram was constructed, Figure 7. 


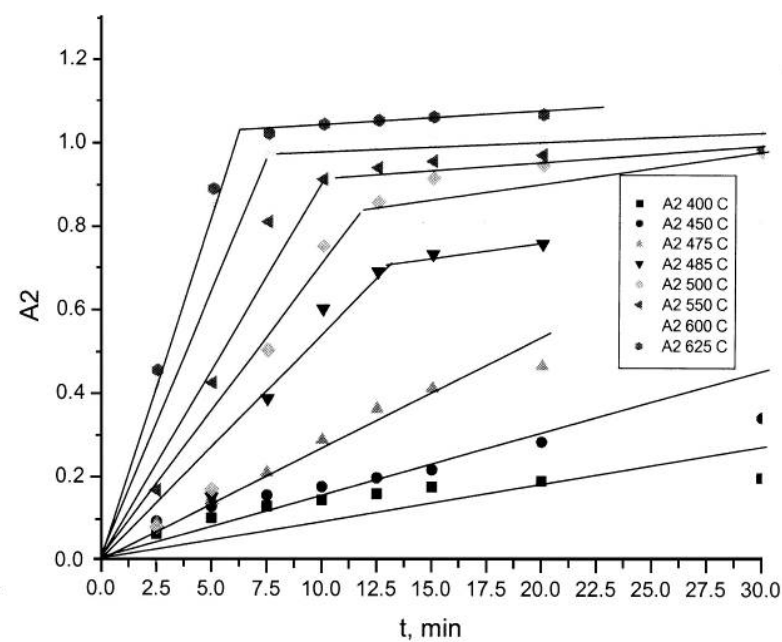

Fig. 6. Linearization of experimental data points using kinetic equation $A_{2}$ for the first stage of the desulphurization process

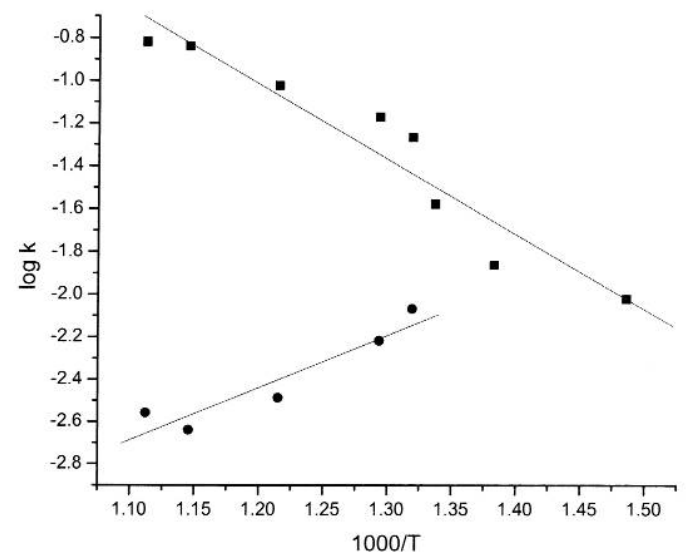

Fig. 7. Arrhenius diagram for the process of oxidative roasting constructed according to the slope of sulphur removal during the process

According to the Arrhenius diagrams, the activation energy of process, under isothermal conditions was calculated. Activation energy is $67 \mathrm{~kJ} / \mathrm{mol}$, for the oxidation process before infraction of liberalized isotherms and $47 \mathrm{~kJ} / \mathrm{mol}$ after it. 


\section{Laboratory Pyrometallurgical Investigations}

\section{Results of Experimental Investigations}

Laboratory experimental investigations were carried out in the laboratories of Mining and Metallurgy Institute Bor on a concentrate sample from Blagojev Kamen with the following content (\%): $\mathrm{Cu}-2.30 ; \mathrm{Fe}-19.80 ; \mathrm{S}-27.90 ; \mathrm{Zn}-9.13$; As 0.167; $\mathrm{Pr}-15.63 ; \mathrm{SiO}_{2}-17.93 ; \mathrm{CaO}-0.97 ; \mathrm{Al}_{2} \mathrm{O}_{3}-1.43 ; \mathrm{Ag}-480 \mathrm{~g} / \mathrm{t} ; \mathrm{Au}-659 \mathrm{~g} / \mathrm{t}$.

Investigations were carried out by smelting the concentrate of $1 \mathrm{~kg}$ concentrate in a graphite tigel in the laboratory Taman's furnace. First investigation was carried out by smelting of unroasted concentrate sample. Two phases were obtained: calcine and slag. Calcine had the following content $(\%)$ : $\mathrm{Cu}-6.81 ; \mathrm{Pb}-9.00 ; \mathrm{Zn}-9.31 ; \mathrm{S}-$ 30.80; $\mathrm{Fe}-40.49 ; \mathrm{Au}-0.129$ and $\mathrm{Ag}-0.094$. Content of calcine was a little bit different from concentrate. Slag was very acidic with the following content: $\mathrm{SiO}_{2}$ 58.0; $\mathrm{CaO}-12.07$.

This method of concentrate smelting does not give the satisfied results because the polymetallic $\mathrm{Cu}-\mathrm{Pb}-\mathrm{Zn}$ calcine is obtained with about $60 \%$ of transfered gold and silver.

The following serie of four samples was carried out according to the following layout: oxidation roasting - smelting with addition of reducer and without reducer in presence of suitable fluxes. Three investigations were carried out with roasting material with content of $7 \% \mathrm{~S}$, and one investigation with roasting material with $3.55 \% \mathrm{~S}$. Smelting of roasting material was carried out with variable quantity of reducer (powdered coal). Smelting of samples of $1 \mathrm{~kg}$ roasting material was carried out in the laboratory furnace in a graphite tigel at $1250^{\circ} \mathrm{C}$.

Graphite tigel was cooled by various intensity. Hardened melt includes three layers - raw lead on the bottom of tigel, $\mathrm{Cu}-\mathrm{Pb}-\mathrm{Zn}$ calcine in the medium part and slag on the suface.

Based on the results of laboratory investigation and literature data, the following technological layout (Figure 8) was defined for treatment the sulphide polymetallic concentrate from Blagojev Kamen: oxidation roasting, charge preparation, smelting, cupellation of raw lead to dóre metal and refining of dóre metal. The first three phases of process were checked in the laboratory conditions (oxidation roasting of concentrate, charge preparation and smelting). 


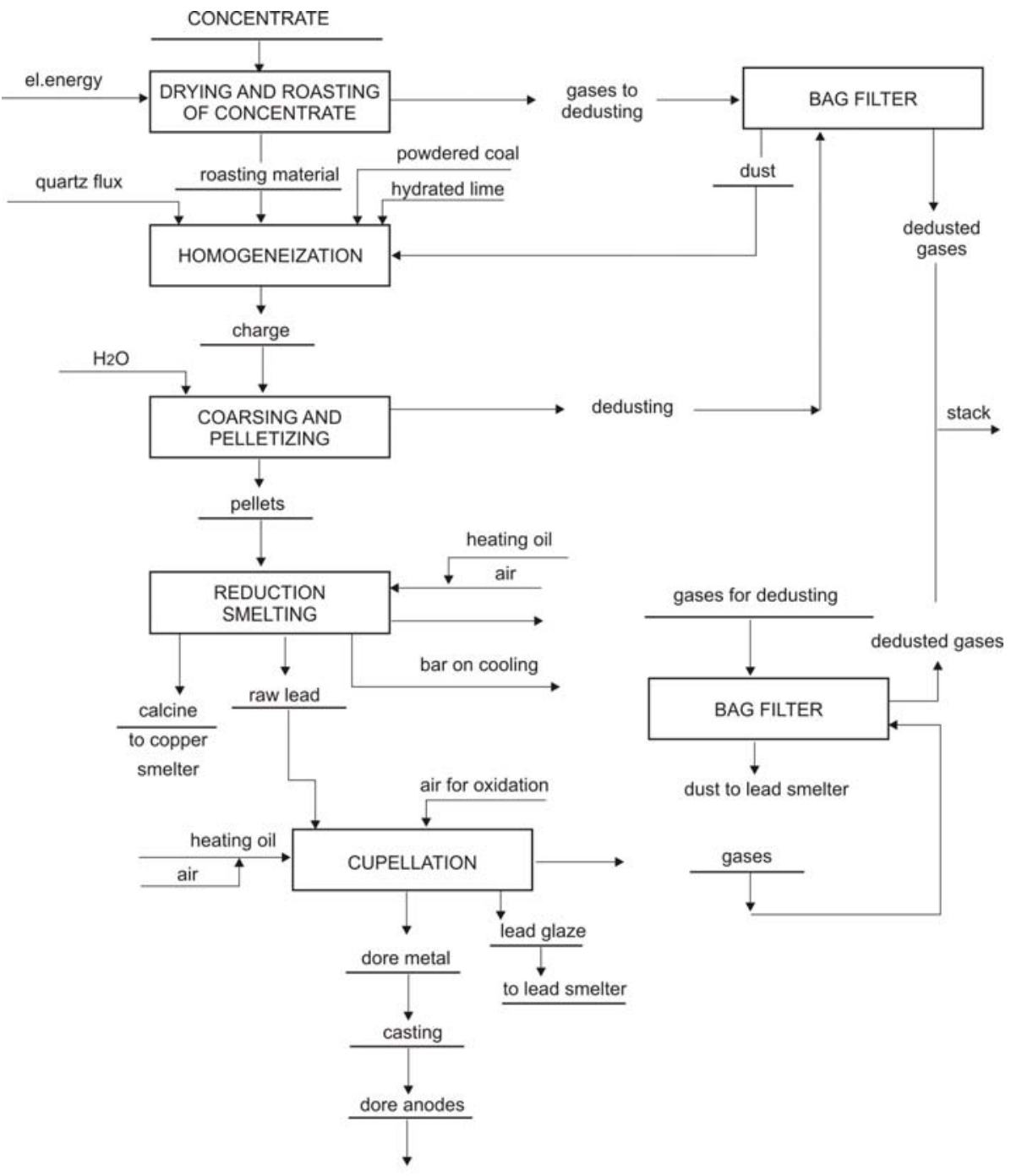

Fig. 8. Block sheme of treatment the goldbearing concentrate from Blagojev Kamen

Metal part is raw lead with content of 91.32 to $96.38 \% \mathrm{~Pb}$ and, by content, lead is very similar to raw lead, produced in the lead metallurgy in a pit furnaces. In our case, content of precious metals, especially gold, is much more higher, in the range of 0.66 to $1.38 \%$, and silver of 0.598 to $1.11 \%$, since in raw lead, produced in the lead metallurgy, content of those metals is much more lower, $1000-5000 \mathrm{~g} / \mathrm{t} \mathrm{Ag}, 1-5 \mathrm{~g} / \mathrm{t} \mathrm{Au}$.

Second phase of smelting process is presented by $\mathrm{Cu}-\mathrm{Pb}-\mathrm{Zn}$ calcine that is also similar to calcine, produced in the lead metallurgy in a pit furnaces. Calcine contains: $15-24 \% \mathrm{~Pb} ; 13.77-42 \% \mathrm{Cu}$; and $2-4 \% \mathrm{Zn}$. Beside this, it also contains of 0.02 to $0.14 \% \mathrm{Au}$ and 0.22 to $0.8 \% \mathrm{Ag}$. 
Third stage of slag smelting has the following content: $\mathrm{SiO}_{2}-36.45 \% ; \mathrm{FeO}-26$ $-31 \%$; and $\mathrm{CaO}-10-20 \%$; and minimum quantity of useful metals: 1 to $1.55 \% \mathrm{~Pb}$; 0.16 to $1.39 \% \mathrm{Cu}$; about $5 \% \mathrm{Zn}$; 0.0006 to $0.001 \mathrm{Au}$; and 0.0055 to $0.25 \% \mathrm{Ag}$.

Transfer degree of useful metals, especially precious metals into raw lead is very high: $\mathrm{Pb}$ from 50.23 to $55.88 \%$; Au from 90.5 to $97.95 \%$ and $\mathrm{Ag}$ from 77.28 to $93.37 \%$. Raw lead, produced in the investigation process, is very good collector for precious metals and, in a case of good smelting process control, nearly total quantity of precious metals is transfered into raw lead.

In the $\mathrm{Cu}-\mathrm{Pb}-\mathrm{Zn}$, the following is transfered: 4.48 to $10.47 \% \mathrm{~Pb} ; 52.35$ to $74.37 \% \mathrm{Cu} ; 1.1$ to $3.92 \% \mathrm{Au}$ and 4.35 to $8.42 \% \mathrm{Ag}$. Calcine presents a reverse material where additional metal recovery could be carried out by supplemental treatment. Unsignificant quantity of metals is transfered into slag: 3.88 to $8 \% \mathrm{~Pb}$; about 0.58 to $1.6 \% \mathrm{Au}$ and 2.45 to $6.28 \% \mathrm{Ag}$. Very low is a transfer degree of gold into slag.

\section{Conclusion}

Investigations the new copperbearing raw materials, which are located on the marginal parts of the main exploited mineral deposit of copper ore, are significant because of the upcoming modernization of the Copper Smelter in RTB Bor.

Goldbearing concentrate with content in (\%) of : $\mathrm{Cu}-2.3$; $\mathrm{Fe}-19.8 ; \mathrm{S}-27.90$; $\mathrm{Zn}-9.13$; $\mathrm{As}-0.167 ; \mathrm{Pb}-15.63 ; \mathrm{SiO}_{2}-17.93$; $\mathrm{CaO}-0.97$; was used for laboratory investigations of pyrometallurgical process the extraction of precious metals. Goldbearing raw material from the locality Blagojev Kamen with content in (\%) of : $\mathrm{Cu}-0.047 ; \mathrm{S}-0.99 ; \mathrm{Pb}-0.11 ; \mathrm{Zn}-0.049 ; \mathrm{SiO}_{2}-87.14, \mathrm{Al}_{2} \mathrm{O}_{3}-1.98 ; \mathrm{Au}-10-15 \mathrm{~g} / \mathrm{l}$; $\mathrm{Ag}-15-25 \mathrm{~g} / \mathrm{l}$; was undergone to the flotation process in the semi-industrial plant of Mining and Metallurgy Institute Bor.

The investigation results of oxidation process in the system $\mathrm{Fe}-\mathrm{Pb}-\mathrm{Zn}-\mathrm{S}$ are presented in this paper. In the first part of paper characterisation the starting sample, including chemical analyses, X-ray diffraction, as well as thermodynamic analysis of phase stability in the characteristic systems, are presented. The process kinetics was investigated using the Sharp method and it was determined that the oxidation process starts rather fast at the beginning of the process (first 6-12 minutes, depending on temperature) with activation energy which places the process in kinetic region. After this first period, activation energy fall to the value on border of kinetic-to-transition area, meaning that diffusion of reactants and product of reaction began to have influence on overall rate of reaction.

Based on the laboratory investigation results and literature data, the following technological layout was defined for treatment the sulphide polymetallic concentrate from Blagojev Kamen: oxidation roasting, charge preparation, smelting, cupellation of raw lead to dóre metal and refining of dóre metal. The first three phases of process were checked in the laboratory conditions (oxidation roasting of concentrate, charge preparation and smelting).

The investigations of technology for goldbearing quartz from the locality of East Serbia were carried out in the laboratories of Mining and Metallurgy Institute Bor. Goldbearing quartz was subjected to the flotation process. Product of flotation concentrate with content of $659 \mathrm{~g} / \mathrm{t} \mathrm{Au}$ and $480 \mathrm{~g} / \mathrm{t} \mathrm{Ag}$ was subjected to the pyrometallurgical treatment: oxidation roasting, reduction smelting. 
Three stages were obtained in the smelting process: raw lead with content of 91.21 to $96.38 \% \mathrm{~Pb} ; 0.74$ to $0.809 \% \mathrm{Au}$ and 0.49 to $0.598 \% \mathrm{Ag}$. $\mathrm{Cu}-\mathrm{Pb}-\mathrm{Zn}$ calcine with content of 15.25 to $24.76 \% \mathrm{~Pb} ; 13.77$ to $41.99 \% \mathrm{Cu} ; 2-4 \% \mathrm{Zn} ; 0.02$ to $0.075 \% \mathrm{Au}$ and 0.036 to $0.128 \% \mathrm{Ag}$. Slag with content of 0.0006 to $0.0013 \% \mathrm{Au}$.

The majority of precious metals from concentrate are transformed into raw lead as well as: 90.5 to $97.95 \% \mathrm{Au}$ and 77.28 to $93.37 \% \mathrm{Ag}$.

The proposed technology for goldbearing quartz treatment consists of the following stages:

- flotation of previous crushed quartz ore,

- oxidation roasting of flotation concentrate,

- reduction smelting,

- cupellation of raw lead even to dore metal,

- refining of dóre metal.

\section{References}

[1] G.V.Samsonov, S.V.Drozdova, Sulfides, Metallurgy, Moscow, 1972. (in Russian)

[2] D.J.Vaughon, J.R.Craig, Mineral chemistry of metal sulfides, Cambridge University Press, Cambridge, 1978.

[3] N.Štrbac, D.Živković, Ž.Živković, I.Mihajlović, Monograph: Sulphides - thermal, thermodynamic and kinetic analysis, Punta, Bor, 2005. (in Serbian)

[4] A.W.Espelund and H. Jynge, Scandinavian Journal of Metallurgy, 6(6) (1977), 256-262.

[5] V.M.Kuzminykh et.al., Izvestiya Vysshikh uchebnykh Zavedenij. Tsvetsnatya Metallurgiya, 2(1984)59-64.

[6] D. Sinadinović, R. Vračar, Ž. Kamberović, CIM Buletin, 94 (1051) (2001) 123 128.

[7] H.J.Sharp,W.G.Brinduy,N.B.Harahari, J.Amer.Ceram.Soc., 49 (1966) 379.

[8] G. Hilson, AJ. Monhemius, Alternatives to cyanide in the gold mining industry: What prospects for the future?, Journal of Cleaner Production 14 (2006) 1158-1167

[9] K. Tanida, M. Hoshino, Continuous Determination Of Mercury Air By Gold Amalgamation And Flameless Atomic Absorption, The Rigaku Journal, Vol. 7, No2, 1990, 35/40.

[10] Gold Amalgamation, http:www.goldprospecting.com 